\title{
Definitions of the Degree of the Potential Erosion Danger of the Mountain Brown Soil of Azerbaijan
}

\author{
RAE ZH Aliyev* \\ Institute of Erosion and Irrigation NAS of Azerbaijan
}

Submission: March 06, 2018; Published: March 19, 2018

*Corresponding author: RAE ZH Aliyev, Institute of Erosion and Irrigation NAS of Azerbaijan, Email: zakirakademik@mail.ru

\begin{abstract}
On plots of fields under crops under crops, the signs on which it is possible to determine the degree of erosion of soils are the inside covering and plant heights. With the enthusiasm of the steepness of the slopes, the possibility of using cultivated crops as indicators of soil erosion decreases. The degree of soil washout period of natural forage lands can be assessed on the basis of the dependence of the existing between the plant stand and the degree of soil erosion. Strongly eroded soil of slope meadows can be recognized by ecological care regimes of habitats of vegetation.
\end{abstract}

Keywords: Eroded; Humus; Medium-washed; Bioclimatic; Dense ground-cenoses; Steppe

\section{Introduction}

In the context of Azerbaijan, the process of erosion has become a large development, calling for a washout, erosion and deflation, etc. types of unwanted consequences of destroying the aggregate properties of soils. It is expressed most clearly in the soils, cultivated in rain fed conditions in the example object. The aim of achieving completeness solvable problems of land management, erosion or potentially dangerous erosion should be deeply know every plot of land in the region, its features that can influence the choice of crops in the territory of the possible only as a result of deep surveys the territory. We should also recognize that the stronger are affected by erosion of the soil, the more they differ from their unwashed analogues on chemical, granulometric composition and physical and chemical properties, water, air and thermal regimes of biogenic and other indicators, which together affect their fertility and erosion resistance [1].

\section{The moves and discuss the results of the study}

As a result, undertaken under the direction of Aliyev $\mathrm{BH}$ [2] research jointly with experts of the Polish Institute of technology revealed that soil erosion is reduced humus content. However, the margin when $0-50 \mathrm{~cm}$ layer in nesmytyh mining and steppe similar Brown soils is 168t/ha, in a very slabosmytyh-156t/ha, slobosmytyh-135t/ha, srednesmytyh108t/ha, silnosmytyh-65t/ha, and in very silnosmytyh-32t/ha.
In eroded soils not only decreases the total humus content, but also decreases the contents of mobile forms of humus acids. According to the author, these changes are the stronger; the more are affected by erosion of the soil.

It is believed that the decrease of humus acids leads to lower fertility, conservation of soil resistance to deterioration. This same decline, in General, proportional to the reduction of nitrogen in the soil. Shortage of available forms of nitrogen is one of the important reasons for the decline of fertility of eroded soils.

Regularity also reveals decreasing $\mathrm{r} 20$ in moderate washed out soils by $30 \%$ and - stronger washed away- more $50 \%$. Reduction of organic phosphates and phosphorus forms insoluble increase leads to deterioration of phosphorus nutrition of plants. In eroded soils are often reduced content of potassium. Thus, its agrochemical characterization of soil washed away are substantially different from unwashed. Hence arises the need for differentiated fertilization in soil with varying degrees of erosion [3].

Results of laboratory studies found that eroded soils differ significantly from not eroded on physical properties. In the eroded soils decreases the content of waterproof structural aggregates.

Table 1: Diagnostic indicators of varying degrees of erosion the mountain- steppe similar Brown soils.

\begin{tabular}{|c|c|c|c|c|c|c|}
\hline \multirow{2}{*}{$\begin{array}{c}\text { The Degree of } \\
\text { Erosion and Its } \\
\text { Designation }\end{array}$} & \multirow{2}{*}{$\begin{array}{c}\text { Power } \\
\text { Horizons a + b }\end{array}$} & Humus & Nitrogen & Phosphorus & $\begin{array}{c}\text { Durable Water Aggregates } \\
\text { more than 1mm }\end{array}$ & Yield kg/ha \\
\cline { 4 - 7 } & 75 & 168 & 10.5 & 6.4 & 52 & 28,5 \\
\hline Not eroded & 70 & 156 & 8.8 & 5.8 & 48 & 26,2 \\
\hline Very little eroded & 75 & &
\end{tabular}




\section{Trends in Technical \& Scientific Research}

\begin{tabular}{|c|c|c|c|c|c|c|}
\hline Weakly eroded & 60 & 135 & 7.6 & 5.0 & 42 & 22.3 \\
\hline Moderately eroded & 45 & 108 & 5.6 & 3.2 & 30 & 15.8 \\
\hline Heavily eroded & 30 & 65 & 3.8 & 2.3 & 18 & 9.8 \\
\hline Very heavily eroded & Less than 15 & 32 & 1.9 & 1.2 & 8 & 6.4 \\
\hline
\end{tabular}

And so, if in the upper horizon of mountain-unwashed Brown step-down soil durable water content of the aggregates is $52 \%$ very slabosmytyh- $48 \%$, slabosmytyh- $42 \%$, srednesmytyh-30\%, strongly washed $18 \%$, and in very silnosmytyh-8\%. The number of units of less than $0.25 \mathrm{~mm}$ increments (Table 1).

Not eroded soils are distinguished from eroded visible differentiation of soil profile and greater capacity. Well allocated arable and 2 layers [4]. In the past appears grayBrown shade effect of alluvium horizon. Subsurface layer is visibly detectable seal and meet the selection of carbonates. Structure of silt-clotted, and Virgin soil-clotted well expressed. The degree of erosion for each soil type is set, depending on which part of the soil profile washed away or deformed horizon from which topsoil is emerging, what is the average percentage yield compared to harvest on/non-eroded soils, and the steepness of slope in degrees.

The degree of erosion of soil also depends on the shape of the slope, its length and exposure, the correctness of management, anti-erosion of sustainability, which includes a variety of mechanical, chemical and physical properties. Therefore, on the slopes of the same slope soils can be one, but different subtype of erosion [5].

The average harvest is a very important indicator in determining the degree of erosion. In the field soil fertility was determined visually by morphological hallmark of a soil profile and as plants on this site. From the data Table 1. It can be seen that as the degree of erosion decreased the power of the horizon $\mathrm{a}+\mathrm{b}$ and reserve of humus within certain limits.

It should be noted that the supply of humus (in tones) is calculated taking into account the nitrogen and phosphorus. In addition, data on crops as listed in the classification of eroded soils, somewhat understated. Our nursery (2008-2010) studies have shown that the harvest of winter wheat at very little eroded mountain-Brown soils in the rolling average is reduced to $10 \%$ for medium-up to $25 \%$ of eroded, and the strong eroded h-up to $75 \%$ compared with crops on soils which not subject to erosion/and approved the results of long-term researches

Table 2: Distribution of arable land on the steepness of the slopes and soil erosion administrative areas of the northeastern part of the Greater Caucasus.

\begin{tabular}{|c|c|c|c|c|c|c|}
\hline \multirow{3}{*}{ Control Areas } & \multirow{3}{*}{ Total Area ha } & \multicolumn{3}{|c|}{ The Steepness of the Slopes } & \multicolumn{2}{|c|}{ Eroded from the Entire Arable Land } \\
\hline & & \multirow{2}{*}{ Cooler $1^{\circ}$, ha/ $\%$} & \multicolumn{2}{|c|}{ Including Steeper } & \multirow{2}{*}{$\begin{array}{c}\text { Total Hectares/ } \\
\text { Percent }\end{array}$} & \multirow{2}{*}{$\begin{array}{l}\text { Including a Strong and Very } \\
\text { badly-Eroded ha/\% }\end{array}$} \\
\hline & & & $5^{\circ}$, ha/\% & $8^{\circ}$ ha/,\% & & \\
\hline Cuba & 20402 & 1502873.7 & 1038550.9 & 289814.2 & 1346566.0 & 284513.9 \\
\hline Kusar & 31586 & 2348574.4 & 1914760.6 & 46.2514 .6 & 2206669.9 & 433313.7 \\
\hline
\end{tabular}




\section{Trends in Technical \& Scientific Research}

\begin{tabular}{|c|c|c|c|c|c|c|}
\hline Davaci & 19421 & 1541879.3 & 1169560.2 & 342017.6 & 1482976.4 & 312716.1 \\
\hline Siyazan & 10767 & 970890.2 & 714263.3 & 213819.9 & 870880.9 & 194218.0 \\
\hline $\begin{array}{c}\text { Khachmaz } \\
\text { branch }\end{array}$ & 39624 & 1422535.9 & 3270.8 & - & 1189030.0 & 5381.4 \\
\hline Total & 121800 & 7786463.9 & 48640.0 & 1308110.7 & 7095858.0 & 1278510.5 \\
\hline
\end{tabular}

However, these are not always equal terms, so the soil more steep slopes may be less inclined than are affected by erosion (Table 2) as can be seen from the table, in the north-eastern part of the Greater Caucasus arable land on terrain conditions are more acceptable-pleasant than the South-East or South of the Greater Caucasus.

Therefore, the soil cover is relatively less eroded. This is largely due to the relatively higher conservation soil stability, acceptable-pleasant rainfall and soil-protective role of vegetation. Acceptable-pleasant rainfall and soil protection role of vegetation. Soil erosion studies in Azerbaijan showed that factor exposure slopes more often affects distribution of eroded soils than the steepness of slopes.

Distribution of arable land on the steepness of the slopes and soil erosion administrative areas of the northeastern part of the Greater Caucasus. Therefore, when conducting a survey in the forest zone, the mountain-brown soils, stepped on one of the areas with a slope of 15-200 on the southern slope of highly prone soil erosion, were found on the slopes of the northern exposure with a slope of 15-200-weak erosion.

It was found a great influence on the distribution of soil exposure. So on the slopes of the Northern exposure when slopes $8-12^{\circ}$ mountain-brown stepped soils wash is $19.2 \mathrm{~m} /$ ha, while similar conditions southern exposure reaches soil washout $45.8 \mathrm{~m} / \mathrm{ha}$. If on the slopes of the southern exposure medium and highly prone to erosion, soils occupy $41.2 \%$ of the area, on the slopes of Northern exposure in similar circumstances-just $9.8 \%$.

Square units of each category and groups of eroded land have been calculated, taking into account the genetic soil types. As a result, became possible be explication of eroded land of Azerbaijan. In explicating contains data on the number of each type of eroded soils varying degrees of erosion on slopes or another surface, consisting of various agricultural land. Further synthesis of erosion of land is to bring them into the Republican maps, where, with the aim of zoning activities rise shows the dependence of the soil cover. To highlight eroded territories the following gradation of the basis for the allocation of eroded land. Based on the data mapping of eroded soils, as well as the cameral works compiled map of soil erosion of the Azerbaijan Republic with the following application:

\section{Area lack of erosion}

o Do not subject to erosion under forests; o Not prone to soil erosion, natural senecos and occupied marsh vegetation;

o Soil, confined to such lands, as deposits, gardens.

Area subject to erosion: Depending on the amount of soil with varying degrees of destruction of genetic horizons lands are divided into five groups:

Very little eroded land: Where weakly washed a difference constitute no more than $10 \%$ and silnosmytye soils are not available.

Weakly eroded land: Where the total area of eroded differences is $25 \%$. Area weakly washed $-20 \%$ medium degree washed away soil-not more than $5 \%$, and strong degree washed away soils are not available.

Middling soil eroded: Only up to $50 \%$ of eroded soils. Square of contours with medium soils eroded reaches $30 \%$, slightly eroded-to $15 \%$ and heavily-eroded -up to $5 \%$ and very heavily-eroded is $10 \%$.

Heavily eroded soils: Jerodirovannost soils is about $75 \%$ of the total area. Of these, silnojerodirovannye- $40 \%$, - mediumeroded- to $25 \%$, and very silnojerodirovannye- $10 \%$.

Highly heavily-eroded soils: Eroded area accounted for more than $75 \%$. Very silnojerodirovannye-bolee $50 \%$, medium, heavily-eroded -more than $25 \%$.

Given our experience, we fully share the views of F.s. Kozmenko, g.a. Presnyakova, S.s., Sobolev K. Alekperova, m.n. Zaslavsky that coloring the top layer of soil can be taken as the rate of erosion.

In not washed -colour dark brown: Humus content- $5 \%$, nitrogen- $0.30 \%$, fosfora_0, $22 \%$, capacity-35m/ekv absorption on $100 \mathrm{~g}$ of soil, structural units resistance to water -mm over $1 \mathrm{~km}$ with $52 \%$.

Very poorly washed away: Horizon and washed not more than $20 \%$, the color of the soil a little different from unwashed (dark brown). Humus content in the upper horizon is $4.6 \%$, nitrogen- $0.28 \%$, phosphorus- $0.19 \%$ absorption capacity$32.5 \mathrm{~mm} / \mathrm{ekv}$ on $100 \mathrm{~g}$ of soil, the number of water resistance

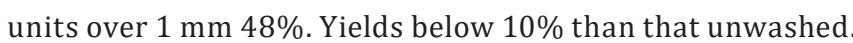

Poorly washed away: Horizon and from 20 to $50 \%$ washed soil color Brown, humus content- $4 \%$, nitrogen- $0.24 \%$, phosphorus- $0.16 \%$, absorption capacity-CIECA 28.8 to $100 \mathrm{~g}$ of soil, the number of water resistance units- $48 \%$. Yields below (from 10 up to $25 \%$ ) unwashed soils. 
Medium washed away: Horizon and washed away completely. soil color is light brown, humu s content-2.8\%-0.18\% nitrogen, phosphorus- $0.10 \%$, absorption capacity is 23.8 CIECA on $100 \mathrm{~g}$ of soil, water resistance units-30\% productivity below from $25-50 \%$ than that of nesmytyh.

Heavily washed away: Wash off the horizon in1, the color of the soil -j yellowish with brownish tinge. The content of humus-1.2\%-0.08\% nitrogen, phosphorus-0.05\%, absorption capacity is 14.5 to $100 \mathrm{~g}$ of soil CIECA, water resistance units-18\%, yield-from 50 to $75 \%$ (Table 3).

Table 3: The degree of soil erosion.

\begin{tabular}{|c|c|c|c|}
\hline $\begin{array}{c}\text { The Degree of } \\
\text { Erosion }\end{array}$ & $\begin{array}{c}\text { Genetic } \\
\text { Horizons } \\
\text { Washout, \% }\end{array}$ & $\begin{array}{c}\text { Reducing } \\
\text { the Stock of } \\
\text { Humus, \% }\end{array}$ & $\begin{array}{c}\text { The Condition } \\
\text { of Crops }\end{array}$ \\
\hline $\begin{array}{c}\text { Very little } \\
\text { eroded }\end{array}$ & (A) up to 20 & $<10$ & Good \\
\hline Weakly eroded & (A) $20-50$ & $10-25$ & $\begin{array}{c}\text { Slightly below } \\
\text { average }\end{array}$ \\
\hline $\begin{array}{c}\text { Moderately } \\
\text { eroded }\end{array}$ & (A) fully & $25-50$ & Average \\
\hline Heavily eroded & In about 50 & $50-75$ & indented \\
\hline $\begin{array}{c}\text { Very heavily } \\
\text { eroded }\end{array}$ & In fully & $>75$ & Very bad \\
\hline
\end{tabular}

Very heavily washed away: Rinse off completely the soil layer on the surface of exposed, loose and hard woods.

General provisions for the classification of eroded soils are the following: selection of diagnostic indicators to determine degrees of erosion of soil, suitable quantity allocated to degrees of erosion soil standards to ascertain their degree of erosion. For mining-Brown soil erosion degree stepped is invited to determine to reduce genetic horizons and reduce the content of humus in the horizons of $\mathrm{a}+\mathrm{b}$. very weak i eroded $\mathrm{t}$ is recommended to classify the soil in which the compared with non-eroded the reduction and horizon to $20 \%$ and up to $10 \%$ of humus, to weakly eroded respectively $10-25 \%$ tomedium-eroded \%,25-50-silnojerodirovanny m-50-75\%. This graduation offered, taking into account the variation in the humus content in soil and unwashed laboratory error definitions [9].

Determination of the degree of erosion of soils based on quantitative change in humus content in the surface layer of soil-is an accurate and objective method that can be used in exposed soil mapping mining-Brown soil and stepped close to him on the genesis of soils.

Natural hayfields and pastures, is constantly covered with vegetation, considered the most effective form of conservation lands. However, due to the deprivation of the protective cover on the slopes increased run-off of soil, which contributes to erosive process.

In their geographical distribution of erosion on pasture appear in a certain area of subordination, which is confined to certain areas and bioclimatic is a product of the evolution of the bio-climatic Wednesday.

Depending on the degree of development of erosive process, the nature of vegetation and soil generic breeds, each selected type of erosion is divided into subtypes and variants.

Grouping of eroded soils of the Republic covers the main natural-landscape zones, taking into account the landscape and climatic conditions of each zone [10].

Highland climate differs harsh long protracted winter snow and frost. Summers are short and cool. The average annual temperature does not exceed $3.2-4.1^{\circ}$, and the coldest month (January) range from $-4.6-7.9{ }^{\circ} \mathrm{C}$, the temperature of the warmest month (July) is low, ranging from 12.9-13.7 ${ }^{\circ} \mathrm{C}$; the sum of temperatures above $10^{\circ}$ very low and average does not exceed 800-600. Duration of the frost-free period 1-2 months, vegetation period lasts 90-120days. Average number of approximately $610-1210 \mathrm{~mm}$, moisture ratio $1.52-1.22$, total solar radiation (annual) changes within 144-156kcal/cm2. For the climatic indicators of the whole territory of the Highlands refers to wet $(\mathrm{MD}<0.45)$ and cold $(\Sigma \mathrm{T}>800)$ climatic type.

Floristic composition of the vegetation is extremely heterogeneous and varies with altitude. In the most elevated part of the vegetation canopy cover not provided-groups rocky (lichens, algae, etc.) For the Alpine meadows are typical dense-ground meadows with cereals components. Subalpine meadows are represented by grain cereals, grasses, thickets of rhododendron and in relatively dry parts of meadow-steppe communities. The main soil types are: mountain-meadow, mountain-forest-meadow and mountain-meadow-steppe. Agricultural production is weak, the zone largely occupied by wealthy summer pastures and mowed lands and are the basis for the development of transhumance (sheep) and fodder production.

Alpine and subalpine meadows, the main area which is occupied by pastures, soil erosion is the factor, which is closely linked areas. Stripped of protective vegetation, soil sloping land can't absorb the snow and rain water. This leads to an obsession with surface runoff which enhances Ripple Rivers. As a result of violations of the hydrological regime of the territory, this is due mainly to the removal of forest and grassy vegetation, knocking in the rivers of the mountain areas often seen very strong fluctuations in the volume of river flow. The large loss of runoff regime of river runoff deteriorates, like snow, and especially the force of snowfall years. This, in its turn, reduces irrigation capacity of rivers on the territory of the foothill Plains, necessitates the use of large irrigation and reclamation work.

Erosive processes that resulted from the degradation of the vegetation of pasture, contributing to a sharp drop in the productivity of pastures. Therefore, soil erosion and deterioration in the quality of grass-processes are closely 
linked. A well-developed natural grass cover markedly increases the resistance of soils and erosion of the leach ate may run off.

A development process of erosion affects not only the quantitative indicators of pasture plants, but also leads to a restructuring of phytocenosis. From the total area of 2402.3hectares of mountain pastures over 1985, 8 thousand hectares or $82.7 \%$ are prone to erosion.

A pasture depending on sub-band and exposure of the slope wash soil varies 50 to $125 \mathrm{~m} 3$ ha. From these studies derives great economical importance is the study of pasture erosion in mountainous areas and the development of techniques to prevent and fight against it. When developing differential measures for the improvement and rational use of pastures, there is always a need for classification and grouping of grazing land for their quality status.

It should be noted, however, that classification pasture erosion has now developed enough. Moreover, even the phenomenon of erosion on pasture do not found a definite place in the common grouping of erosive processes, although the nature of the manifestations of pasture erosion is very much different from other types or categories of erosion.

On the classification of eroded soils of mountain pastures known works of some author: VA Meeting, DJ Mihjlova, SW Kerimhanova.

In these works gives grouping soils grazing on a degree as they are destroyed. In the forms of accelerated erosion caused by human activities, have a lot in common. However, according to and from the reasons caused the manifestation of erosion, these forms have their own characteristics.

The character manifestation of soil erosion of mountain pastures pretty sharply differs from erosion on cultivated hillsides. Erosion processes on the pastures start to develop normally, since damage to the turf.

Mountain pasture soil destruction process has no similarities with the formation of gullies and potholes. The length of the pits not always exceeds their width, and availability under lower-powered soil layer waterproof dense rocks brings not on no growth pits deep. Further growth in the size of erosion pits usually occurs through the broken walls, sliding down the slope of sod places preserved woven roots and reminiscent of education in the second stage of its development. Raised near each other erosive pits are often steep walls and expand, incorporate among themselves, forming patches or streaks of eroded soil. As the further destruction of the soil occurs more or less gradual alignment of through the shedding of micro relief, and under the influence of sloping lands runoff.
This specificity of the appearance of erosion on mountain pastures requires, firstly, providing pasture erosion in independent or category subtype, secondly, development of appropriate soil classification according to the degree of their erosion.

Based on long-term observations, taking into account the peculiarities of the destructive processes of soils under the influence of the unrestrained grazing of livestock, it is proposed that the draft classification pasture erosion on erosion degree (Table 4). This includes the sequence of tufted deformation process layer.

Table 4: Classification of pasture erosion on hillsides.

\begin{tabular}{|c|c|c|}
\hline Stage & The Degree of & Indicators \\
\hline \multirow{4}{*}{$\begin{array}{c}\text { Embossment } \\
\text { (tropinnity) }\end{array}$} & Very weak & $\begin{array}{c}\text { The total area of paths: }<10 \% \text { of } \\
\text { the account area }\end{array}$ \\
\cline { 2 - 3 } & Weak & $10-25 \%$ \\
\cline { 2 - 3 } & Average & $25-50 \%$ \\
\cline { 2 - 3 } & Strong & $50-75 \%$ \\
\cline { 2 - 3 } & Very strong & $75 \%$ \\
\hline
\end{tabular}

Research indicates the possibility of using cultural vegetation cropland and grass native grasslands in order to clarify the erosive soil survey data.

\section{References}

1. Alekperov KA (1980) Pochvoezionnaya map and land protection. Moscow, Russia.

2. Aliev BH (2005) The problem of desertification in Azerbaijan and ways to solve it, "Ziya-Naji” publishing house Baku, Azerbaijan.

3. Zaslavsky MN (1969) To the draft classification of soils according to the degree of erosion. Sat. Materials on the methodology of soil-erosion mapping of erosion control measures.

4. Zaslavsky MN (1983) Erosiology, publishing house Higher School.

5. Ibrahimov AA (2001) Mapping of eroded soils on agricultural lands, (on the example of the Dashkesan region of the Azeri SSR.

6. Ibrahimov AA (2000) Agro ecological feature of eroded soils of Azerbaijan. Materials on the study of erosion and irrigation and soil conservation in Baku, Azerbaijan.

7. Sobelyov SS (1948) The development of erosion processes on the territory of the European part of the USSR and the struggle against them. Publishing House of the USSR Academy of Sciences 1.

8. Sobolev SS (1961) Protection of soils from erosion.

9. Filkov VA (1958) Soil-erosional zoning of the Kamensk and Rostov regions. Sb. «Soil erosion and struggle with it», Moscow, Russia.

10. Jozefacik A, Jozefacik CZ (1995) Erozya aqroekosystemow. Panstwowa Inspekcya Ochrony Srodowicka. Warszawa: Putawwy as IUNG. 168. 


\section{Your next submission with Juniper Publishers will reach you the below assets}

- Quality Editorial service

- Swift Peer Review

- Reprints availability

- E-prints Service

- Manuscript Podcast for convenient understanding

- Global attainment for your research

- Manuscript accessibility in different formats ( Pdf, E-pub, Full Text, Audio)

- Unceasing customer service

Track the below URL for one-step submission https://juniperpublishers.com/online-submission.php 